\title{
Why Withdrawal Rights?
}

\author{
Horst EIDENMÜLleR*
}

\begin{abstract}
Almost every legal system accepts the fundamental principle that promises must be kept ('pacta sunt servanda'). Yet, a consumer's right to withdraw from a contract for the purchase of goods or services ('withdrawal right') figures prominently in European consumer law directives, in the ACQP and in the DCFR. Withdrawal rights imply a significant weakening of the fundamental principle pacta sunt servanda. However, the popular invocation of withdrawal rights is not rooted in a thorough analysis of the purposes such rights might fulfill. This article attempts to provide such an analysis by posing the central normative question: 'Why Withdrawal Rights?'. It uses the tools of (behavioral) economics to identify three situational categories in which granting a withdrawal right may be justified: information asymmetries at the time of contract formation, exogenous distortions of the consumer's preferences and endogenous distortions. The article also seeks to assess the effectiveness of withdrawal rights in achieving their stated objectives. It contains specific policy recommendations with respect to the mode in which withdrawal rights should be granted, if they are granted at all (i.e. mandatory versus optional, etc.).
\end{abstract}

Résumé: La force obligatoire du contrat figure parmi les principes fondamentaux de presque tous les ordres juridiques. Pourtant, les droits de rétractation sont un des instruments essentiels des directives européennes concernant la protection des consommateurs, et ils ont aussi un rôle important dans les Principes acquis (ACQP) ainsi que dans le projet de Cadre commun de référence (PCCR). De tels droits impliquent une atteinte signifiante du principe fondamental 'pacta sunt servanda'. La popularité des droits de rétractation ne se fonde pas sur une analyse à fond des objectifs que de tels droits pourraient poursuivre. Cet article entreprend de présenter une telle analyse en posant la question normative fondamentale: 'Pourquoi des droits de rétractation?'. En appliquant des conceptions de l'économie comportementale, trois situations sont identifiées dans lesquelles un droit de rétractation pourrait être justifié: Une asymétrie d'information lors de la conclusion d'un contrat, des perturbations des préférences exogènes du consommateur et des perturbations des préférences endogènes. L'article vise aussi à apprécier l'efficacité des droits de rétractation quant à l'accomplissement de leurs buts. Il contient des propositions spécifiques concernant le mode dans lequel un droit de rétractation, s'il y a lieu, devrait être accordé (par droit impératif, en forme d'option etc.).

Kurzfassung: In nabezu allen Rechtsordnungen gebört es zu den grundlegenden Prinzipien, dass Verträge eingehalten werden müssen. Gleichzeitig sind Widerrufsrechte für Verbraucher

* Professor for Private Law, German, European and International Company Law at the Ludwig Maximilian University, Munich (Research Professorship), and Visiting Professor (on a continuing basis) at Oxford University. I should like to thank participants in research seminars at the University of Amsterdam (Martijn Hesselink) and at the Max Planck Institute for Research on Collective Goods (Christoph Engel/Martin Hellwig) for interesting discussions and an anonymous reviewer for helpful comments and suggestions. 
ein wesentliches Instrument der europäischen Verbraucherschutzrichtlinien, und sie spielen auch in den ACQP und im DCFR eine wichtige Rolle. Solche Rechte implizieren eine signifikante Schwächung des fundamentalen Prinzips 'pacta sunt servanda'. Die Popularität von Widerrufsrechten berubt nicht auf einer gründlichen Analyse der Zwecke, die solche Rechte möglicherweise erfüllen können. Der Aufsatz unternimmt es, eine solche Analyse vorzulegen, indem er die zentrale normative Frage stellt: 'Warum Widerrufsrechte?' Unter Anwendung (verbaltens-)ökonomischer Konzepte werden drei Konstellationen identifiziert, in denen die Einräumung eines Widerrufsrechts gerechtfertigt sein könnte: Informationsasymmetrien bei Vertragsschluss, exogene Präferenzstörungen des Verbrauchers und endogene Präferenzstörungen. Der Artikel versucht auch, die Effektivität von Widerrufsrechten im Hinblick auf die Erreichung ibrer Zwecke zu beurteilen. Er enthält spezifische Vorschläge hinsichtlich der Art der Einräumung von Widerrufsrechten (durch zwingendes Recht, als Option etc.), sofern diese überhaupt eingeräumt werden sollten.

Pacta sunt servanda is a principle which is fundamental to a liberal system of private law. In short, contract law dictates that each person is bound by the contracts into which he or she has voluntarily entered. This principle is also fundamental with respect to the efficiency of a legal system. If it did not exist, long-term agreements could not be easily reached for fear that enforcement would be impractical. Contract law would be more or less confined to agreements governing on-the-spot contracts, with performance taking place immediately upon formation. Long-term exchanges would need to be self-enforcing, for example due to bilateral or multilateral security rights, or supported by other extralegal mechanisms. For a highly developed exchange economy, this would clearly be a step backwards.

Notwithstanding the historically proven importance of pacta sunt servanda, the principle has slowly been eroded in Europe ${ }^{1}$ over recent decades due to the proliferation of withdrawal rights. Such rights are an important element of the European consumer law acquis and its further development. They grant consumers an option to withdraw from a contract within a specified time period. The option is conditioned on specific factual situations surrounding the contract formation or granted with respect to specific contract types. Provided the option exists, it may be exercised at the consumer's discretion. In other words, in certain situations, the consumer is entitled to withdraw from a contract for whatever reason he or she likes or without any reason at all.

This article aims at assessing the normative foundations of withdrawal rights as an instrument of consumer protection. The central question addressed is:

1 For the US see C. Camerer, S. Issacharoff, G. Loewenstein, T. O’Donoghue and M. Rabin, 'Regulation for Conservatives: Behavioral Economics and the Case for "Asymmetric Paternalism”' (2003) 151 U Pa L Rev 1211, 1240-1242; D.J. Morgan, 'The Right to Rescission, Still Controversial After All These Years’ (1995) 49 Fin L Q Rep 177. 
When do withdrawal rights make sense, and why? The article takes a critical stance towards the proliferation of withdrawal rights in the European consumer law acquis. It argues that a withdrawal right should only be granted if, in a particular case setting, its benefits clearly outweigh its costs. On this basis, withdrawal rights are justified in far fewer circumstances than the European consumer law acquis leads us to believe.

After a brief description of the European legal status quo (I), I will lay out the conceptual foundations that will guide the normative analysis in the following sections (II). The central part of this article is devoted to identifying three different factual situations which may justify granting a withdrawal right: information asymmetries, exogenously distorted preferences of the consumer and endogenously distorted preferences (III). These economic categories roughly correspond to the distance selling context, doorstep transactions, and timesharing/credit/life insurance contracts, respectively. I will further develop some ideas as to how the effectiveness of withdrawal rights could be enhanced (IV), and I will attempt to answer the question of whether withdrawal rights should also be granted to businesses $(\mathrm{V})$. The main findings will be summed up in the conclusion of this article (VI).

\section{Legal status quo}

The legal status quo with respect to European withdrawal rights is characterized by a set of directives that grant such rights to consumers. These are the following directives: (1) Directive 85/577/EEC to protect the consumer in respect of contracts negotiated away from business premises; (2) Directive 2008/122/EC on the protection of consumers in respect of certain aspects of timeshare, long-term holiday product, resale and exchange contracts; (3) Directive $97 / 7 / \mathrm{EC}$ on the protection of consumers in respect of distance contracts; (4) Directive 2002/65/EC concerning the distance marketing of consumer financial services; (5) Directive 2008/48/EC on credit agreements for consumers; (6) Directive 2002/83/EC on life insurance. The first directive mainly concerns what has come to be known as doorstep selling transactions, and the second refers to timeshare contracts. The third and the fourth directive relate to distance selling, and the fifth to credit contracts. The sixth directive stipulates a cancellation right for all policy holders under a life insurance contract, including consumers.

Of note, however, withdrawal rights do not only figure prominently in the existing European consumer law directives. They are also an important element of the Acquis Principles (ACQP) ${ }^{2}$, and as such they have made their 
inroad into the Draft Common Frame of Reference (DCFR) ${ }^{3}$. No withdrawal rights are to be found in the Principles of European Contract Law (PECL). Work on the PECL began before the European consumer rights directives were passed. Withdrawal rights do not exist in the UNIDROIT Principles of International Commercial Contracts either, as these principles do not concern consumer contracts.

The acuteness of the normative question central to this article becomes obvious once one looks for justifications of withdrawal rights in the abovementioned consumer law directives. Recital 23 of Directive 2002/65/EC concerning the distance marketing of consumer financial services, for example, makes the following claim: 'With a view to optimum protection of the consumer, it is important that the consumer [...] has a right of withdrawal.' This statement begs the question - Why? - yet does not answer $\mathrm{it}^{4}$. This is even more problematic as the withdrawal right granted by Directive 2002/65/EC is also stipulated, without further reflection, for all credit agreements (see recital 34 of Directive 2008/48/EC).

In the two cases mentioned, withdrawal rights have been granted by the European legislature without any justification being proffered. More recently, new withdrawal rights have been proposed on a basis which is very dubious at least. Recital 14 of the proposal for a directive on consumer rights ${ }^{5}$, for example, seeks to justify the sweeping proposal of granting a withdrawal right with respect to all contracts concluded off-premises: 'In an off-premises context, consumers are under psychological pressure no matter whether they have solicited the trader's visit or not'. The assumption underlying this sentence is controversial and, at least in its generality, untenable. Further, no critical reflection on this important point is to be found in the Commission's proposal, nor in recital 14 or anywhere else in the text. Similar to the proposal for a directive on consumer rights, the ACQP and the DCFR also suggest that consumers should have a withdrawal right with respect to all off-premises contracts (Articles 5:201 ACQP, I.-5:201 DCFR). Again, no justification is offered for why this should be so. In short, withdrawal rights are endorsed as an instrument of consumer protection without proper reflection.

Hence, it is clear that offering a coherent and compelling justification for withdrawal rights is an important academic and policy task. As withdrawal rights entail a significant erosion of the pacta sunt servanda principle, advocat-

3 Art II.-5:201 and II.-5:202 DCFR.

4 For a similar claim see Recital 45 of Directive 2002/83/EC concerning life insurance: 'For life assurance contracts the policy holder should be given the opportunity of cancelling the contract within a period of between 14 and 30 days.'

$5 \operatorname{COM}(2008) 614$ final. 
ing them without an understanding of when and how they make sense is inadvisable.

\section{Conceptual foundations}

Withdrawal rights grant an option to withdraw: the consumer entitled to the right may withdraw from an agreement, but he or she is not forced to withdraw nor commit to the execution of the agreement. The optional character of withdrawal rights corresponds to the potential impairment of the consumer's will formation, in the sense of his or her intention to be bound, as the basis of the withdrawal right. Something might have been wrong with this will formation process, but we do not know for sure. However, the consumer can exercise the withdrawal right under any circumstance, regardless of whether he or she originally intended to be bound by the contract and fully understood the terms of the agreement. In other words, withdrawal rights allow a consumer to avoid contractual obligations simply because he or she changed their mind, or, for example, because more attractive offers became available.

Justifying withdrawal rights crucially depends on the specific measuring rod used. There are good reasons to assert that private law rules should primarily be designed on the basis of their efficiency effects. Such rules are ill-suited to achieve redistributive goals ${ }^{6}$. Hence, I will assess the merits of withdrawal rights based on whether and under which circumstances they enhance economic efficiency. From an economic standpoint, the fundamental principle is easily stated: withdrawal rights should be granted only if their benefits outweigh their costs. This is clearly a very abstract formula. Therefore, it is central to the understanding of these rights that we attempt to categorize the types of costs and benefits which are presumptively associated with withdrawal from a contract in particular factual settings.

Turning to the costs first, these come in various forms: exercising withdrawal rights involves transaction costs; there is legal uncertainty during the exercise

6 Contrast H. Eidenmüller, F. Faust, H.C. Grigoleit, N. Jansen, G. Wagner and R. Zimmermann, 'The Common Frame of Reference for European Private Law - Policy Choices and Codification Problems' (2008) 28 OJLS 659, 672, with M.W. Hesselink, CFR E Social Justice (München: Sellier, 2008).

7 The advantage of such an abstract formula is that it leaves room to identify different fact patterns and associated normative rationales based on which stipulating withdrawal rights might be justified. As to this, see the following sections of this article. Contrast this approach with the model constructed by O. Ben-Shahar and E.A. Posner, 'The Right To Withdraw in Contract Law', http://ssrn.com/abstract=1569753 (March 14, 2010), 5 et seq. By focusing on only one relevant aspect - uncertainty of the buyer about how much he or she values a good - the authors lose sight of many fact patterns and normative rationales for granting a withdrawal right. 
period, and there are costs associated with delayed or abandoned consumption $^{8}$. It is important to note that in a competitive market, all the costs just mentioned are ultimately borne by all consumers. They bear the costs triggered by those consumers who can be characterized as 'withdrawal rights users'. To put it differently, withdrawal rights are paid for by all consumers, regardless of whether they wish to have and/or to exercise such rights9.

Whereas the costs associated with (the exercise of) withdrawal rights come in different forms, the principal benefit is only one, and it can be stated as follows: withdrawal rights are a tool to counteract the performance of inefficient contracts. A contract is inefficient if a consumer contracts goods or services, the price - and costs in the competitive market - of which exceeds the benefit to the consumer. A consumer might enter into such a contract due to some form of irrationality and/or impairment of the will formation process. The precise conditions under which this might happen will be spelled out in later sections of this article.

In the policy debate on withdrawal rights, such rights are sometimes defended with the argument that they strengthen consumer confidence in specific distribution channels such as distance selling ${ }^{10}$. Such a benefit, however, is very hard to quantify. Moreover, granting withdrawal rights irrespective of their cost-benefit effects on the micro level of specific transactions would surely be over-inclusive: withdrawal rights would exist even though, on that level, they are clearly not worth their costs. It is not convincing to advocate withdrawal rights as a means to inspire consumer confidence regardless of their necessity as a protective tool on the micro level.

The cost-benefit analysis presented thus far is complicated by the fact that entering into and performing an inefficient contract might have an 'educatory function', ie long-term efficiency benefits. To hold someone to a contract that he or she would not have entered into upon proper reflection creates a negative experience for this person. However, it will give the individual an opportunity to learn, and to behave more astutely in the future. Such learning experiences are, in principle, desirable. However, the consequences of holding someone to an inefficient contract are sometimes so grave that the likelihood of that person

8 However, the last cost mentioned (abandoned consumption) is a relevant cost only if a withdrawal right is exercised even though the contract was efficient in the first place (ie, if the withdrawal right should not have been exercised). What is meant by an 'efficient contract' will be explained immediately in the text.

9 See G. Borges and B. Irlenbusch, 'Fairness Crowded out by Law: An Experimental Study on Withdrawal Rights' (2007) 163 JITE 84, 87 (10\% of all customers are 'responsible' for $40 \%$ of all withdrawals).

10 See 'Commission presents results of Eurobarometer on consumer protection in the Internal Market', http://europa.eu/rapid/pressReleasesAction.do?reference=IP/06/ $1268 \&$ format $=$ HTML\&aged $=0$ \&language $=\mathrm{DE} \&$ guiLanguage $=$ en . 
engaging in a similar transaction in the future becomes very slight. Think, for example, of the grave financial consequences stemming from a particular transaction where the future actions of the consumer are significantly limited by the agreement. As a consequence of the foregoing analysis, the following general principle can be stated: granting a withdrawal right in a particular case setting is only justified if the benefits of such a right clearly outweigh the associated costs. The case for a withdrawal right is strongest if the consequences of not being able to withdraw from an inefficient contract are grave for the consumer.

Finally, the question arises as to whether contract practice is a good indicator for the efficiency of withdrawal rights. As is well-known, the Coase theorem holds that efficient arrangements will tend to emerge provided that market transactions are possible and transaction costs are not prohibitively high ${ }^{11}$. However, it is clear that the conditions under which the Coase theorem operates do not necessarily hold in the context in which withdrawal rights might be justified. This is so because reasons which may justify granting a withdrawal right in a particular case setting might be exactly those that affect the efficiency of the consumer's contract decision and, as a consequence, the efficiency of contractual practice in that particular case setting.

As an intermediate conclusion it can be stated that withdrawal rights should be granted only if their benefits clearly exceed their costs in a specific setting. Contract practice is not a reliable indicator to determine whether these conditions hold.

\section{Justifying withdrawal rights}

In the following sections, three different rationales will be discussed which may justify granting withdrawal rights in particular case settings: information asymmetries, exogenously distorted preferences of the consumer, and endogenously distorted preferences. These three rationales correspond to three transaction types that are currently governed by different directives of the European withdrawal rights regime: distance selling, doorstep transactions, and timesharing/credit/life insurance contracts.

\section{Information asymmetries}

In economic theory, a distinction is made between search goods, experience goods and credence goods ${ }^{12}$. Search goods are goods whose quality can be

11 R. Coase, 'The Problem of Social Cost' (1960) 3 J Law E Econ 1.

$12 \mathrm{Cf}$ Ph. Nelson, 'Information and Consumer Behavior' (1970) $78 \mathrm{~J}$ Pol Econ 311; 
ascertained upon inspection. An example would be unpacked fruits in a shop. There is clearly no need for granting a withdrawal right to consumers with respect to the purchase of search goods. The consumer is immediately able to identify whether the good in question suits his or her interests upon inspection in the shop.

Credence goods are goods whose characteristics can be observed by the consumer neither prior to the transaction nor after purchase or consumption. An example of a credence good are the services provided by a medical professional or a lawyer. A non-professional will have difficulty in ascertaining the quality of the services, and such difficulty will exist both before and after the transaction. Hence, withdrawal rights do not make much sense with respect to credence goods, as a consumer would not normally be able to make sensible use of such a right. As the consumer is not in the position to determine whether the contract is efficient in the first place, the withdrawal right period will elapse without a considerate exercise of the right being possible.

Experience goods are goods whose product characteristics are only ascertainable upon inspection and consumption. An example would be dinner in a restaurant. Whether a particular good is an experience good can depend on the distribution channel by which the good is marketed and the way in which it is presented in a store. Distance selling, for example, can 'create' experience goods that would be search goods if sold in a shop.

As is well-known, information asymmetries with respect to experience goods can lead to market failure because of adverse selection ${ }^{13}$. Buyers who are uncertain about the quality of the good purchased will assume a medium quality standard. High quality vendors will not be able to charge high prices for their goods, as buyers will not be willing to honor such high quality since they are incapable of recognizing it. Hence, the average quality of the goods offered deteriorates, and the market for a particular good may even break down ${ }^{14}$.

This dynamic is an important one especially in the distance selling context. A consumer that sees a particular product, for example a piece of clothing, offered on a website, will often be unsure whether the product is really suitable or will fit. Hence, the consumer is uncertain whether the good in question will provide a benefit that is worth the associated costs. As a consequence, the

M. Darby and E. Karni, 'Free Competition and the Optimal Amount of Fraud' (1973) 16 $J$ Law E Econ 67.

13 G. Akerlof, 'The Market for "Lemons": Quality Uncertainty and the Market Mechanism' (1970) 84 Q J Econ 488.

14 This is not discussed by M.B.M. Loos, 'Rights of Withdrawal', http://ssrn.com/abstract $=1350224$ (February 27, 2009), 7 et seq, in his critique of withdrawal rights in the distance selling context. 
consumer might adjust his or her willingness to pay accordingly, ie offer only a price reflecting the probability that upon receipt of the good it turns out that its anticipated value is not reached. Hence, the total sales volume might be lower than it would be in the absence of such information asymmetries.

Vendors can give various signals about the quality of their offerings, thereby reducing information asymmetries and preventing market failure. Such signals will be most effective in achieving this end if it is less costly for high quality sellers to send them as compared to low quality sellers. For example, a signal of that kind may be found in the form of a guarantee. A high quality vendor can signal high quality products at low costs by issuing a guarantee. Given the high quality of the product, the associated guarantee costs are comparatively low. Along those lines, withdrawal rights can also be explained as a signal. Vendors who anticipate that consumers will only make use of such rights on rare occasions, because the products purchased have a high value, can offer withdrawal rights cheaply.

If it is true that withdrawal rights can work as a voluntary device used by vendors in the distance selling context to overcome information asymmetries, the next important question is this: why should withdrawal rights be granted by mandatory law, i.e. why should businesses be forced by law to offer consumers contracts that provide withdrawal rights? In the following sections, I endeavour to answer this question by discussing three different policy options with respect to a withdrawal rights regime in the distance selling context. A first subsection will deal with withdrawal rights as a mandatory rule, which reflects the status quo according to Directive $97 / 7 / \mathrm{EC}$ on the protection of consumers in respect of distance contracts, and Directive 2002/65/EC concerning the distance marketing of consumer financial services. In the following subsections I will then discuss withdrawal rights as merely a default rule, and finally withdrawal rights as a regime to be chosen - as an option - by the consumer.

\section{a) Withdrawal right as a mandatory rule (status quo)}

Under the European legal status quo just described, consumers have a mandatory entitlement to a withdrawal right with respect to distance selling contracts. A consumer cannot waive this entitlement even though he or she may wish to contract without a withdrawal right at a possibly lower price. The parties are stuck with the regime as prescribed by the law. Given that this withdrawal rights regime involves a significant erosion of the pacta sunt servanda principle, only compelling reasons could justify this legal status quo.

Such compelling reasons do not exist. Withdrawal rights may be agreed to voluntarily between contracting parties, even where no such entitlements exist 
as a matter of statutory law. Large retailers in particular offer the right to withdraw from the agreement with respect to on-premises purchases, and there are also cases in which withdrawal rights are offered vis-a-vis businesses as customers ${ }^{15}$. Obviously, the signalling mechanism described in the previous section works to overcome information asymmetries on a voluntary basis. It is true that it has also been argued in a previous section of this article that contract practice is not a reliable indicator with respect to the efficiency of withdrawal rights. However, contract practice is such an indicator with respect to distance selling and the overcoming of information asymmetries. Here, the consumer's contract decision is not twisted due to some exogenously or endogenously induced irrationality ${ }^{16}$. Rather, the problem of market failure due to information asymmetries arises even if, or precisely because, all market participants behave in a completely rational manner.

Voluntarily providing a withdrawal right as a signal in the distance selling context would be easy. As with respect to payment or delivery details or other similar contractual issues, the consumer could simply be offered the option to 'check the box' if he or she wished to conclude a contract with a right to withdraw. The added transaction costs of such a regime would be negligible. All in all, no compelling case can be made for granting a withdrawal right as a mandatory rule in the distance selling context. Hence, the current legal status quo is unsatisfactory and should be changed.

\section{b) Withdrawal right as a default rule}

If it is true that there are no compelling reasons to force a permissive, nonwaivable withdrawal right on the consumer in the distance selling context, such a right might at least be provided as a default rule. Under such a regime, the statutory withdrawal right of the consumer could be contracted away by the parties. To justify this rule, one could point to the fact that it might reflect

15 For examples see H. Eidenmüller, 'Party Autonomy, Distributive Justice and the Conclusion of Contracts in the DCFR' (2009) 5 ERCL 109, $126 \mathrm{n} 32$. See also Ben-Shahar and Posner, $\mathrm{n} 7$ above, 4 et seq.

16 It is true that vendors sometimes do apply manipulative tactics also with respect to distance selling transactions. For example, they might seek to trick consumers into contracts by taking advantage of surprise effects, etc. However, this is a rather rare problem created by a minority of dishonest or even criminal merchants. Moreover, other private law rules such as those on the conclusion of contracts (Was there really acceptance?), mistake, misrepresentation, etc., should offer sufficient protection to the consumer. Finally, it is far easier for a consumer to withstand such tactics when having the opportunity to reflect calmly on the sensibility of a particular contract when sitting behind his or her computer at home than when confronted with aggressive sales tactics in a shop or on the street. 
the typical interests of the parties and thus economizes on transaction costs. This, of course, is the rationale typically put forward to justify a default rule.

However, this economizing effect might exist only for certain transactions. In other words, it is unclear whether each and every consumer in every distance selling transaction actually desires to have a withdrawal right. The consumer in question is best positioned to assess whether a withdrawal right is worth its associated costs. However, under a default rule regime the consumer cannot make this decision unilaterally. The most likely result is that businesses would deviate from the withdrawal right in their standard terms - perhaps not all businesses, but at least a significant portion. Then the courts would need to review the efficiency of the withdrawal right if such terms were challenged. As the courts do not have a clear picture regarding the costs and benefits related to the right of withdrawal with respect to different consumers, they are not in a good position to make this decision.

Hence, it must be concluded that no compelling case can be made for a withdrawal right as a default rule in the distance selling context. The main criticism that must be levelled against this regime is that it fails to allocate the decision competence with respect to the desirability of a withdrawal right to the most appropriate party, namely the consumer ${ }^{17}$.

\section{c) Withdrawal right as an optional regime}

This deficiency of stipulating a withdrawal right in the distance selling context as a default rule might be remedied by a regime under which the withdrawal right would be a statutory option for the consumer. Under this regime, the consumer must be offered a choice between a contract with and without a right to withdraw. This option would force the consumer to decide whether such a right would be worth the higher price for the withdrawal opportunity. In essence, this regime would conceive a withdrawal right in the distance selling context as an insurance of the consumer against the risk of finding out after the delivery that the product or service contracted is not worth the price paid. The additional price for having the withdrawal option is the insurance premium' that must be borne by the consumer.

A clear advantage of this regime is that only those consumers who benefit from such rights would contract and pay for the option to withdraw ${ }^{18}$. Hence, some form of separating equilibrium would emerge in which two types of contracts

17 Ben-Shahar and Posner, n7 above, 20, who advocate withdrawal rights as a default regime, fail to see this.

18 To be more precise, a consumer purchasing the withdrawal option will have to bear the expected costs associated with the withdrawal right, ie the costs discounted by the probability of withdrawal. 
in the distance selling context would exist: contracts with withdrawal rights for a slightly higher price and contracts without withdrawal rights for a slightly lower price. The price differential will, in a competitive market, reflect the marginal costs of the businesses and thus be small ${ }^{19}$. Therefore, consumers will not be able to act opportunistically by buying goods with a withdrawal right, returning them after having exercised the right, and then buy them again much cheaper without a withdrawal right. As long as there is no significant price differential between the two types of contracts, such opportunistic action would be limited to rare cases. Further, under these circumstances, vendors would not be able to act strategically by charging exorbitantly high prices for contracts containing the right to withdraw. Competitive forces will drive the price of the 'insurance premium' down to the marginal costs of the vendors.

With respect to the specific form in which the consumer must exercise his or her choice, both an opt-out and an opt-in solution are conceivable. Under the former, the consumer would have a withdrawal right unless he or she chose by 'checking the box' - not to have it. Under the latter regime, the consumer would have the ability to opt-in to the withdrawal rights regime by 'checking the box'. It is difficult to foresee what the choice frequency under these two regimes exactly would be. Endowment effects might make the withdrawal right sticky under an opt-out regime ${ }^{20}$. However, framing effects might work in a different direction. If the consumer chose not to have a withdrawal right by opting out, this could be presented as a contract with a discount price ${ }^{21}$. The overall direction of the effects is unclear. A third and neutral mode of the optional regime would be to ask the consumer to check either of two boxes, i.e. a contract with a withdrawal right and a contract without.

A potential argument against the proposed regime could be that consumers might systematically underestimate the risk of entering into inefficient contracts and hence might not purchase the withdrawal option even if this were useful in a particular case. It is true that there is empirical evidence that in-

19 See, for example, http://www.bonprixservice.de/bp/bestellung/belohnt.html (offering a discount of EUR 3 for the next purchase if withdrawal right with respect to the previous transaction is not exercised).

20 On such effects see, for example, R. Thaler, 'Towards a Positive Theory of Consumer Choice' (1980) 1 J Econ Behav E Org 39, 44; D. Kahneman, J.L. Knetsch and R.H. Thaler, 'Experimental Tests of the Endowment Effect and the Coase Theorem' (1990) 98 J Pol Econ 1325, 1342; D. Kahneman, J.L. Knetsch and R.H. Thaler, 'Anomalies: The Endowment Effect, Loss Aversion, and Status Quo Bias' (1991) 5 J Econ Persp 193, 194 et seq; H. Eidenmüller, Effizienz als Rechtsprinzip: Möglichkeiten und Grenzen der ökonomischen Analyse des Rechts (3 ${ }^{\text {rd }}$ ed, Tübingen: Mohr Siebeck, 2005) 125 et seq.

21 See Ch. Bühring-Uhle, H. Eidenmüller and A. Nelle, Verhandlungsmanagement: Analyse, Werkzenge, Strategien (München: C H Beck, 2009) 39 et seq. 
dividuals are overly optimistic ${ }^{22}$. More specifically, however, the evidence suggests that individuals consistently overestimate objectively small probabilities and underestimate large ones ${ }^{23}$. As concluding an inefficient contract is rather unlikely objectively, this effect seems to suggest that too many withdrawal options would be purchased. Moreover, distance selling transactions usually involve low value consumer goods, and consumers usually engage in such transactions repeatedly. There seem to be sufficient possibilities for learning to occur should a particular consumer discover that he or she makes mistakes in the sense of purchasing without a withdrawal right even though having such a right would have been useful with respect to a certain transaction. Hence, consumers should be willing to opt for the withdrawal regime in sufficient quantity.

The crucial question again is why the aforementioned regime, ie an optional withdrawal right, should be mandatory in the sense that the law would stipulate that consumers must be given the choice described. There are a couple of reasons for this. First, there is the economic interest in contract standardization. Having a uniform optional withdrawal rights regime would likely serve to lower transaction costs. Second, legal certainty and transparency would be fostered by such a uniform regime. Third, even though the regime would be mandatory, consumers would gain more freedom relative to the legal status quo by having an option that they do not now have. Finally, vendors would not have a good reason to complain, as they would be compensated for granting a withdrawal right if the consumer so elected, by being able to charge a slightly higher price. Hence, vendors would not be worse off compared to the status quo.

The option model just described should apply to distance selling of experience goods. However, a case may be made to apply it to distance selling in general, that is to say also with respect to credence goods. In a previous section it was argued that credence goods information asymmetries do not disappear after the conclusion of the contract and therefore withdrawal rights are only of limited use as a consumer protection device. However, with respect to distance selling there are less opportunities to clarify problems and give advice by vendor personnel as compared to on-premises negotiations. Moreover, the option model developed does not force consumers into a withdrawal rights regime. Further, it is fair to vendors as they are able to charge a slightly higher price for a contract with a withdrawal right. Finally, as previously noted, there is an economic interest in contract-standardization. Hence, requiring that

22 B. Fischhoff, P. Slovic and S. Lichtenstein, 'Knowing with Certainty: The Appropriateness of Extreme Confidence' (1977) 3 J Exp Psych: Hum Perc E Perf 552.

23 A. Rapoport, Decision Theory and Decision Practice (Dordrecht: Kluwer, 1989) 116. 
vendors provide a withdrawal right option to the consumer with respect to distance selling in general is a defensible policy choice ${ }^{24}$.

However, this option model should not be applied to on-premises contracts. With respect to such contracts, uncertainty relates primarily to product quality and is addressed by legal rules on product quality. Moreover, uncertainties with respect to product use and utility can be reduced by inspection and communication with vendor personnel. The option model developed in this section should therefore not be extended to on-premises contracts.

As an intermediate conclusion it can be stated that in the distance selling context, information asymmetries with respect to product use and utility can lead to market failure. Granting consumers a withdrawal right can be a device to counteract these asymmetries and the resulting potential market failure. Consumers should be given an option to choose between a contract with and a contract without a withdrawal right.

\section{Exogenously distorted preferences}

Inefficient contracts exist where information asymmetries prevent the consumers from correctly appreciating the utility of a particular product or service. However, such contracts may also result from distortions of the consumers' preferences stemming from exogenous sources. Consumers' contract decisions can be distorted by various external influences. Surprise, time pressure, psychological entrapment, the inability to easily terminate contract negotiations, and other manipulative tactics might all contribute to a particular contract decision being based on the distorted preferences of a consumer ${ }^{25}$.

As a consequence, the contract decision of the consumer itself might be inefficient: the consumer purchases goods or orders services for which he or she has no use or for which the use-related value is at least lower than the price which, in a competitive market, reflects the costs of the seller. If the distortion of the consumer's preferences normally corrects itself in a cooling-off period, granting a withdrawal right can be a sensible policy choice.

A good example for this is the withdrawal right under Directive 85/577/EEC for contracts concluded during an excursion or on occasion of a visit to the consumer's home ${ }^{26}$. With respect to the latter (also known as doorstep sales), it

24 However, as will be shown later in the text, in the case of timesharing and credit contracts, endogenous preference distortions of the consumers might justify even more rigid protection in the sense of an unconditional withdrawal right.

25 For an overview with respect to 'rationality traps' in negotiations see Bühring-Uhle, Eidenmüller and Nelle, n 21 above, 38 et seq.

26 Identifying specific factual situations in which a withdrawal right is granted will both be over- and underinclusive in the sense that not everybody who finds himself or herself in 
is the irritation caused by the vendor that is most relevant for justifying the withdrawal right; the decisive factor with respect to excursions is the inability to leave the scene easily other than by entering into a contract. The withdrawal right must be available under these circumstances as the preference distortion of the consumer would also affect his or her decision for or against a withdrawal right ${ }^{27}$. In other words, it is clear that with respect to the type of distortions that occur in the doorstep selling context, contract practice is not a reliable indicator for the efficiency of a withdrawal right.

Much less convincing than granting a withdrawal right in the doorstep selling context is the recent development in the ACQP, the DCFR, and the draft consumer rights directive towards a withdrawal right for all off-premises contracts. The only reason put forward to justify this sweeping extension of the legal status quo is the surprise effect that is allegedly present with respect to off-premises contracts ${ }^{28}$. It is argued that the consumer does not anticipate engaging in a business transaction off-premises and hence is caught off guard when faced with contractual negotiations under such circumstances. This is a relevant consideration, though not a strong one. This is already made clear by the long list of exemptions that we find in the ACQP, the DCFR, and the draft consumer rights directive as related to the general principle of granting a withdrawal right with respect to all off-premises contracts ${ }^{29}$. Moreover, manipulative tactics and tricks are applied even more forcefully regarding contracts concluded on-premises. This is the vendor's natural environment, and we can all certainly recall the last time when we bought something in a shop solely in an effort to free ourselves from the persistent and unnerving approaches and tactics of the vendor. Compared to off-premises negotiations it is also more difficult to terminate negotiations in the vendor's shop ${ }^{30}$. In

such a situation needs protection, whereas others who find themselves in another (but similar) situation would need protection. However, this is the necessary consequence of typing. On this see S. Lorenz, Der Schutz vor dem unerwünschten Vertrag (München: C H Beck, 1997) 166 et seq.

27 This rationale for the mandatory nature of the withdrawal right has nothing to do with asymmetric information, however, as Ben-Shahar and Posner, $\mathrm{n} 7$ above, 20, believe.

28 See P. Møgelvang-Hansen, E. Terryn and R. Schulze, in Research Group on Existing EC Private Law (Acquis Group), Principles of the Existing EC Contract Law (Acquis Principles) - Contract I: Pre-contractual Obligations, Conclusion of Contract, Unfair Terms (München: Sellier, 2007) art 5:201 margin no 3.

29 With respect to the draft consumer rights directive see art 12 for the general principle (right of withdrawal) and art 19(2), 20(1) and 20(2) for the exceptions.

30 It is noteworthy that affording protection (only) for all off-premises contracts provides insufficient protection in certain cases in which such protection is warranted. On the basis of the definitions in art 2(8) and 2(9) of the draft consumer rights directive, the consumer - different from the legal status quo - does not enjoy the benefit of a withdrawal right when he or she participates in an excursion, but concludes the contract thereafter on the premises of the organizer or a third party. On this problem see B. Jud 
addition, the surprise effect can be present there as well. For example, one might enter a bank simply to withdraw some money only to find oneself roped into some kind of sales negotiations by the bank's employees regarding an unwanted financial product.

Hence, there is clearly no compelling reason to differentiate between offpremises contracts and on-premises contracts with respect to the potential exogenous distortions that influence the consumer's choice. These two types of transactions should be treated alike. However, stipulating a general withdrawal right for all contracts, wherever they are concluded, is not warranted. It would only be justified if the assumption were correct that a great majority of contracts are one-sided, in the sense that the consumers purchased goods or services for which they fail to derive a use that exceeds the price they paid. This assumption has no plausible basis. Granting a right to withdraw for all contracts, wherever they are concluded, would also be counterproductive with respect to long-term efficiency. Every contract would insure the consumers against the risk that something might be wrong with the contract decision in a small number of cases. This approach would destroy all incentives for consumers to reflect in advance, ie before contract formation, on whether the price of the good or service offered exceeds its anticipated value to the consumer. Such consequences are not in line with the image of the 'confident consum$e^{\prime 3}{ }^{31}$. Fostering erratic consumption 'at all costs' is not a sensible economic or political goal.

By way of a further intermediate conclusion it can be stated that exogenously distorted preferences of consumers justify granting a (mandatory) withdrawal right in the doorstep selling context. However, there are no persuasive arguments to stipulate such a withdrawal right for all contracts concluded offpremises. It is not reasonable to assume that the great majority of contracts concluded off-premises are inefficient and hence justify the stipulation of a (mandatory) withdrawal right.

\section{Endogenously distorted preferences}

Individual contract decisions might not only be distorted because of exogenous effects. Internal, psychological effects may also play a role. In recent

and Ch. Wendehorst, 'Proposal for a Directive on Consumer Rights - an Academic Position Paper' (2009) 6 GPR 68, 70; Ch. Wendehorst, 'The CFR and the Review of the Acquis Communautaire', in M. Schmidt-Kessel (ed), Der gemeinsame Referenzrabmen: Entstehung, Inbalte, Anwendung (München: Sellier, 2009) 323, 340.

31 The 'confident consumer' figures prominently in the ECJ's jurisprudence. See, for example, ECJ, Case 252/07 (Intel v CPM), Judgment of 27 November 2008, margin no 34: ‘. . . average consumers ... who are reasonably well informed and reasonably observant and circumspect .... 
decades, many systematic deviations from the assumption of fully rational behaviour have been discovered by cognitive psychologists: individuals are overly optimistic ${ }^{32}$, they work with hyperbolic discount functions $s^{33}$, they falsely rely primarily on available information ('availability bias') ${ }^{34}$, and they also falsely rely too much on the status quo as opposed to deviations from it ('status quo bias') ${ }^{35}$. As a starting principle, one might say that a withdrawal right is justified where grave distortions appear to typically exist but which normally vanish in the cooling-off period.

The current legal status quo assumes that this is the case with respect to timesharing agreements, credit contracts, and life insurance contracts. However, it is not readily apparent why this should be so. On its face, the complexity of the agreements in question seems to justify a withdrawal right. Consumers have difficulty understanding complex transactions and assessing their consequences fully and rationally. The problem is that this defect does not change during the cooling-off period, ie we do not have good reason to believe that we are better positioned to assess these effects after contract conclusion than prior to it. One might even go so far as to make the claim that the prospect of contract formation should sharpen our intellectual capabilities: 'Depend upon it, Sir, when a man knows he is to be hanged in a fortnight, it concentrates his mind wonderfully. ${ }^{36}$

Apart from the complexity of timesharing agreements, credit contracts, and life insurance contracts, the long-term effects of these agreements might be a factor that could justify granting a withdrawal right. However, such effects also exist with respect to other types of contracts, for example long-term leases, for which no withdrawal right is stipulated by law. Further, long-term effects are likely better addressed by legal rules on mandatory consultation before contract formation and rules on contract termination. Hence, longterm effects do not seem to be a compelling argument to justify withdrawal rights for these types of contracts.

Finally, timesharing agreements, credit contracts and life insurance contracts often involve grave financial consequences for consumers. Moreover, apart from potential endogenous preference distortions, exogenous distortions are quite often simultaneously present as well, ie the consumer acts under the manipulative influence of vendor personnel ${ }^{37}$. Stipulating a withdrawal right

32 See n 22 above.

33 D.I. Laibson, 'Golden Eggs and Hyperbolic Discounting' (1997) 112 Q J Econ 443.

34 A. Tversky and D. Kahneman, 'Availability: A Heuristic for Judging Frequency and Probability’ (1973) 5 Cogn Psychol 207.

35 W. Samuelson and R.J. Zeckhauser, 'Status Quo Bias in Decision Making' (1988) 1 J Risk E Uncert 7.

36 J. Boswell, The Life of Samuel Johnson (London, 1823 [1791], vol III) 171.

37 See also P. Mankowski, Beseitigungsrechte (Tübingen: Mohr Siebeck, 2003) 241 et seq. 
that must be exercised within a cooling-off period would give the consumer time to reflect, and seek counsel from peers or advisors. Taken together, all the above-mentioned factors likely make up a sufficiently good case for stipulating a right of withdrawal with respect to timesharing agreements, credit contracts, and life insurance contracts.

These factors are not necessarily present with respect to the distance selling of financial products. For example, if such products are bought over the internet, the vendor cannot apply the same manipulative tactics as are very often used in direct conversations which take place on the vendor's premises. However, if no withdrawal right exists once a credit contract or other financial products are marketed via distance selling, competitive distortions with respect to different distribution channels for financial products would arise. Hence, stipulating a withdrawal right for timesharing agreements, credit contracts, and life insurance contracts is a defensible policy choice, regardless of the distribution channel used for the sale of these products.

As with withdrawal rights in general, consideration should be given as to why the proposed regime should be mandatory. Granting consumers a withdrawal right with respect to timesharing agreements, credit contracts, and life insurance contracts only as an optional regime might enhance their awareness for problems related to their own choice. It might even increase the usage of the right in those cases where the consumers actually opt for it. On the other hand, the potential irrationality related to the decision to contract might also influence the decision for or against a withdrawal right. Moreover, there is the potential simultaneous presence of exogenous preference distortions originating from the vendors' personnel. Hence, the regime should actually be mandatory for all timesharing agreements, credit contracts, and life insurance contracts $^{38}$.

As a further intermediate conclusion it can be stated that endogenously distorted preferences support granting a mandatory withdrawal right with respect to timesharing agreements, credit contracts, and life insurance contracts. In sum, the complexity of the agreements in question, their long-term effects and in particular the very often grave financial consequences for the consumers, and the simultaneous presence of exogenous preference distortions justify the proposed regime.

\section{Enhancing the effectiveness of withdrawal rights}

It is one thing to consider whether, under certain circumstances, withdrawal rights may be used as a sensible tool to counteract the performance of ineffi-

38 This is not appreciated by Ben-Shahar and Posner, $\mathrm{n} 7$ above, 20. 
cient contracts. Another question is whether, under the assumption that such circumstances can be identified, withdrawal rights are effective in achieving their purpose. There are various reasons to be concerned that the effectiveness of withdrawal rights under the current European legal status quo is not as high as it could be. First, it should be acknowledged that withdrawal rights are exercised at a relatively low rate. Independent empirical studies have found that the rate of exercising the right ranges between 2 percent and 5 percent in doorstep selling transactions, and between 15 percent and 35 percent in distance selling transactions ${ }^{39}$. In explaining these figures and their differences, one might hypothesize that in doorstep transactions the great majority of contracts are apparently efficient. By contrast, in the distance selling context a significant number of transactions apparently involve 'try out' purchases. However, these rationales might not be the only ones that explain the relatively low exercise rate of withdrawal rights, especially with respect to doorstep transactions. Other factors might also play a role, such as the reduction of cognitive dissonances and endowment effects ${ }^{40}$. Both psychological phenomena might lead consumers to retain a particular good just purchased even though before the transaction the use value of the good was below the purchase price, ie even though the contract is inefficient.

There are good reasons to disregard endowment effects with respect to policy choices based on an efficiency calculus. It is as arbitrary to pick offer prices as it is to pick asking prices in determining the value of a particular good to the

39 See Bundestag-Drucksache 10/2876 of 15 February 1985, 7 et seq (before the introduction of the statutory withdrawal right with respect to doorstep transactions, only approximately $1,8 \%$ of the voluntarily provided withdrawal rights in Germany were actually exercised); Office of Fair Trading, Doorstep selling: A report on the market study, 2004, Annex L, http://www.oft.gov.uk/shared_oft/reports/consumer_protection/ oft716l.pdf, 49 (according to a British survey conducted in 2003, the exercise rate with respect to withdrawal rights relating to doorstep transactions is around $6 \%$ ); Borges and Irlenbusch, $\mathrm{n} 9$ above, 88 (exercise rate with respect to withdrawal rights relating to distance selling contracts in Germany rose from $24,2 \%$ in 1998 to $35,0 \%$ in 2004); Deutscher Industrie- und Handelskammertag (DIHK)/Trusted Shops, Auswertung der Umfrage zur Praxis des Widerrufs im Fernabsatz bei Warenlieferungsverträgen auf der Basis von 385 Rückantworten, http://www.trustedshops.de/shop-info/wp-content/ uploads/2010/08/umfrage_widerrufsrecht.pdf (according to a DIHK survey among 385 German retailers in 2010 , the exercise rate with respect to distance selling contracts ranges from $12,8 \%$ [gifts] to $28,5 \%$ [shoes, clothing]).

40 On cognitive dissonances see L. Festinger, A Theory of Cognitive Dissonance (Stanford: Stanford University Press, 1957). On the effect of 'dissonance reduction' on the exercise rate of withdrawal rights see $\mathrm{H}$. Eidenmüller, 'Der homo oeonomicus und das Schuldrecht: Herausforderungen durch Behavioral Law and Economics' (2005) 60 Juristenzeitung 216, 218, 221; J.A. Blumenthal, 'Emotional Paternalism' (2007) 35 Fls St U L Rev 1, 62. On endowment effects see the references cited in $n 20$ above. On the relevance of such effects on the exercise rate of withdrawal rights see Eidenmüller, op cit, 218 et seq and 221 et seq. 
consumer ${ }^{41}$. Selective perception as a consequence of the desire to reduce cognitive dissonances, however, is a serious problem because situations might arise in which a plainly inefficient contract is not terminated by the consumer even though the consumer holds a right to withdraw.

One possibility to counteract this effect would be to change the structure of the withdrawal regime. Instead of giving the consumer an option to withdraw from an agreement, the law could stipulate that such withdrawal would occur automatically upon the end of the withdrawal period unless the consumer explicitly confirms the agreement ${ }^{42}$. Under this 'confirmation regime', the consumer would be required to affirm the contract if he or she wished to be bound. This would work against the dissonance reduction and selective perception problem just described, and would enhance the effectiveness of the 'withdrawal right' granted as well. On the other hand, such a system would certainly raise the costs of contracting, since the majority of contracts would actually be confirmed. Moreover, the proposed regime would also reward opportunistic consumer behaviour: It would incentivise consumers to strategically purchase goods or services for temporary use which would then be returned upon expiration of the 'withdrawal period'. Finally, the 'confirmation regime' would surely not be justified in case of optional withdrawal rights as proposed in this article for distance selling transactions. If a consumer has deliberately chosen to have a withdrawal right, there is no reason to alert the consumer as to the existence of that right or his or her ability to exercise it once it has become exercisable. On balance then, the better arguments support retaining the status quo. A duty to confirm an agreement that has already been concluded should not be required.

Another instrument to enhance the effectiveness of withdrawal rights might be special instructions on the existence of such rights. An empirical study in the UK has revealed the surprising fact that 34 percent of consumers believe they have more rights when buying at a local shop as compared to doorstep purchases ${ }^{43}$. Apparently, the consumers are not well informed with respect to their withdrawal rights. The current European rules under the various directives on the consumers' instructions with respect to the existence of withdrawal rights differ significantly ${ }^{44}$. Standardization in this area would be helpful. There should be one standardized set of (electronic) instructions on the existence of a withdrawal right for all types of withdrawal rights.

41 See D. Kennedy, 'Cost-Benefit Analysis of Entitlement Problems: A Critique' (1981) 33 Stanf L Rev 387.

42 For this proposal see Eidenmüller, n 40 above, 222.

43 Office of Fair Trading, Doorstep selling: A report on the market study, 2004, http:// www.oft.gov.uk/shared_oft/reports/consumer_protection/oft716.pdf, 6 .

44 Contrast, for example, art 4 of the doorstep selling directive with art 4 et seq of the timesharing directive. 
Finally, lowering the costs of exercising the right to withdraw might also be a sensible means to enhance effectiveness of these rights. Again, the current European legal status quo under the various directives with respect to how a withdrawal right must be exercised is characterised by some diversity ${ }^{45}$. It would enhance legal transparency and increase the effectiveness of withdrawal rights if, as a general rule, the law would provide that a withdrawal right may be exercised by any declaration in any form that clearly expresses the will to withdraw (this would be in line with Article 6 of the distance selling directive $)^{46}$.

A more difficult question, however, is whether relieving consumers from costs of unwinding the contract and potential damages for loss in value of the goods purchased would be an appropriate measure. Again, the existing European directives provide somewhat diverse rules ${ }^{47}$. The ECJ has recently clarified some of the issues in the Messner/Krïger case $\mathrm{e}^{48}$. It is of course true that the lower the costs levied upon the consumer, the higher the rate of consumer withdrawal will be ${ }^{49}$. On the other hand, opportunistic consumer behaviour should be discouraged ${ }^{50}$. Retailers report a significant number of cases in which goods such as wedding dresses and evening wear are 'borrowed' for a singular event ${ }^{51}$. Hence, allowing businesses to shift the costs of sending back the goods purchased appears to be a sensible rule, as is a potential responsi-

45 Contrast, for example, art 7 of the doorstep selling directive with art 7 of the timesharing directive.

46 See also Loos, $\mathrm{n} 14$ above, 17 et seq.

47 Contrast, for example, art 6(2) of the distance selling directive with art 8(2) of the timesharing directive and art 17 of the draft consumer rights directive.

48 ECJ, Case 489/07 (Messner v Krüger), Judgment of 3 September 2009 (holding that art 6(1) and art 6(2) of the distance selling directive must be interpreted as precluding a provision of national law which provides in general that, in the case of withdrawal by a consumer within the withdrawal period, a seller may claim compensation for the value of the use of the consumer goods acquired under a distance contract; however, those provisions do not prevent the consumer from being required to pay compensation for the use of the goods in the case where he has made use of those goods in a manner incompatible with the principles of civil law, such as those of good faith or unjust enrichment, on condition that the purpose of the distance selling directive and, in particular, the efficiency and effectiveness of the right of withdrawal are not adversely affected, this being a matter for the national court to determine). See also ECJ, Case 511/08 (Heinrich Heine), Judgment of 15 April 2010 (holding that art 6(1) and art 6(2) must be interpreted as precluding national legislation which allows the supplier under a distance contract to charge the costs of delivering the goods to the consumer where the latter exercises his right of withdrawal).

49 However, empirical studies show that the costs of sending back the goods purchased influence the purchase decision only marginally in the first place, see Borges and Irlenbusch, $n 9$ above, 98 .

50 See also Ben-Shahar and Posner, 7 above, 16.

51 See the results of the DIHK study, n 39 above, answers to questions 9a and 11a. 
bility of consumers for damages to the goods that are not necessarily associated with unpacking and inspecting the goods upon their receipt. For example, a consumer's use of the goods purchased over a specified period of time, and within the withdrawal period, should give rise to a responsibility of the consumer to pay the vendor for the loss of value of the goods sold. Such loss of value is equivalent to the use value obtained by the consumer, as the value of a particular good consists of the discounted sum of all use opportunities provided by the good ${ }^{52}$.

As a further intermediate conclusion it can be stated that the effectiveness of withdrawal rights should be enhanced by standardizing the instructions with respect to the existence of such rights and by lowering the costs of a withdrawal. However, changing the structure of a withdrawal right by stipulating a duty to validate or confirm an already completed agreement would not be justified.

\section{Beyond the consumer}

Thus far, the discussion in this article has been based upon the premise that withdrawal rights are a consumer protection tool. However, Directive 2002/ 83/EC concerning life insurance already stipulates a cancellation right for all policy holders under a life insurance contract, be they consumers or not. Similarly, some countries grant withdrawal rights to businesses with respect to certain transactions. Germany, for example, provides in Section 8 of the Versicherungsvertragsgesetz [Insurance Contract Act] since 1 January 2008 that all types of insurance contracts which last for longer than one month are subject to a fourteen day withdrawal right. This right is also granted to businesses entering into such contracts.

The concept of full harmonization that is central to the draft consumer rights directive ${ }^{53}$ would not, if actually adopted, prevent member states from extending withdrawal rights beyond the consumer. That concept would only be applicable in the domain of consumer rights, i.e. it would prevent member states from granting consumers more or less rights than set forth in the directive. It would not, however, prevent member states from also extending withdrawal rights to businesses that are not 'right holders' in the ambit of the consumer rights directive.

However, such extension would not be justified. Considering exogenous and endogenous preference distortions first, commercially active parties are much less irrational and far more informed than the typical consumer. They have

52 Similarly Loos, n 14 above, 21 et seq.

53 See art 4 of the draft directive. 
certain experience with aggressive sales practices, and time pressure, etc. Hence, businesses' typical situation differs from that of regular consumers even though there might be exogenous and/or endogenous distorted preferences in individual cases. Since a sound policy basis for withdrawal rights must look to the typical effects in certain case settings, granting businesses a withdrawal right would not be justified ${ }^{54}$.

However, the situation with respect to distance selling transactions might be considered differently. It is true that businesses can also be expected to suffer less from information asymmetries than do consumers. On the other hand, it has been noted in a previous section that with respect to distance selling transactions withdrawal rights should only be optional. Consequently, extending that optional regime to businesses would be a justifiable policy decision, also because it would contribute to a standardization of contract practice. Apart from this specific case, however, withdrawal rights are a consumer protection tool, and should remain so.

\section{Summary and conclusion}

Withdrawal rights have become an important element of the European consumer law acquis and its further development. They figure prominently in a number of European consumer law directives, in the draft directive on consumer rights, in the ACQP, and in the DCFR. However, this prominence of withdrawal rights as a consumer protection tool is not matched by a profound analysis of their normative foundations. This article has attempted to address the pressing issue of the following fundamental question: when do withdrawal rights make sense and why? The main conclusions of the article may be summarised as follows:

1. Withdrawal rights involve a departure from the fundamental principle of pacta sunt servanda. Hence, offering a coherent and compelling justification for withdrawal rights is an important academic and policy task.

2. Withdrawal rights should be granted only if their benefits clearly exceed their cost.

3. In the distance selling context, information asymmetries might lead to market failure. In this context, vendors should be obliged to provide consumers an option to contract with a withdrawal right.

4. Exogenously distorted preferences justify providing a mandatory with-

54 See also C.-W. Canaris, 'Wandlungen des Schuldvertragsrechts - Tendenzen zu seiner Materialisierung' (2000) 200 Archiv für die civilistische Praxis 273, 349 et seq, 359 et seq; Ben-Shahar and Posner, $\mathrm{n} 7$ above, 20 et seq. 
drawal right in the doorstep selling context - but not for all contracts concluded off-premises.

5. Endogenously distorted preferences justify providing a mandatory withdrawal right with respect to timesharing agreements, credit contracts, and life insurance contracts.

6. The effectiveness of withdrawal rights could be enhanced by standardizing the instructions on the existence of withdrawal rights and by lowering the costs of withdrawals.

7. Withdrawal rights are a consumer protection tool, and should remain so.

If these results are compared to the current European legal status quo, to the academic principles reflected in the ACQP and the DCFR, and to European policy plans, the two following main conclusions emerge: (1) As opposed to the current European legal status quo, withdrawal rights in the distance selling context should only be optional; (2) Plans to extend withdrawal rights to all off-premises contracts should be dropped. 